\title{
Kepraktisan Penggunaan Multimedia Interaktif pada Pembelajaran Tematik Kelas IV SD
}

\author{
Maharani Putri Kumalasani \\ PGSD Universitas Muhammadiyah Malang \\ mahadev_koy46@yahoo.co.id
}

\begin{abstract}
Abstrak
Multimedia interaktif salah satu media pembelajaran yang telah banyak diterapkan di sekolah dasar, hal ini membuktikan bahwa perkembangan teknologi pendidikan sudah merambah pada tingkat sekolah. Multimedia Interaktif merupakan media alternatif yang dapat membantu siswa belajar dengan aktif. Hal ini membuat peneliti tertarik untuk melihat lebih dalam bagaimana tingkat kepraktisan multimedia interaktif digunakan di sekolah dasar. Penelitian ini bertujuan untuk melihat tingkat kepraktisan penggunaan multimedia interaktif pada pembelajaran tematik kelas IV SD. Instrumen yang digunakan berupa pedoman wawancara dengan guru dan angket kepraktisan yang diberikan guru, observer, dan siswa. Hasil analisis dari angket oleh guru diperoleh persentase 90,6\%, dimana persentase tersebut termasuk dalam kriteria "Sangat Praktis". Berdasarkan hasil analisis angket dari observer menunjukkan 90\% dengan kriteria "Sangat Praktis". Sedangkan hasil angket siswa menunjukkan 94,2\% dengan kriteria "Sangat Praktis". Dapat disimpulkan bahwa kepraktisan penggunaan multimedia interaktif dalam pembelajaran tematik kelas IV termasuk dalam kriteria sangat praktis untuk digunakan dalam proses pembelajaran. Multimedia interaktif sebagai salah satu alternatif media pembelajaran untuk menjadikan pembelajaran lebih berkualitas.
\end{abstract}

Kata Kunci : multimedia interaktif, kepraktisan

\begin{abstract}
Interactive multimedia one of the learning media that has been widely applied in elementary school, it is proved that the development of educational technology has penetrated at the school level. Interactive Multimedia is an alternative medium that can help students learn actively. This makes the researcher interested to see more deeply how the level of practicality of interactive multimedia is used in elementary schools. This study aims to see the practicality level of the use of interactive multimedia in the fourth grade thematic learning elementary school. The instruments used are teacher interviews and practicality questionnaires given by teachers, observers, and students. The results of the analysis from the questionnaire by teachers obtained percentage of 90.6\%, where the percentage is included in criteria Very Practical. Based on the results, the questionnaire of analysis from observer showed $90 \%$ with criteria Very Practical. While, the student questionnaire results is show $94.2 \%$ with criteria Very Practical. It can be concluded that the practicality of using interactive multimedia in the fourth-grade thematic learning is included in criteria very practical for use in the learning process. Interactive multimedia as one of the alternative media learning to make learning more quality.
\end{abstract}

Keywords: interactive multimedia, practicality 


\section{PENDAHULUAN}

Perkembangan ilmu pengetahuan dan teknologi (IPTEK) bergerak secara dinamis seiring dengan perkembangan zaman. IPTEK juga mempengaruhi tuntutan masyarakat terhadap dunia pendidikan sebagai kebutuhan primer dimasa mendatang, sehingga dunia pendidikan tidak memungkinkan lagi jika hanya dikelola dengan sistem tradisional. Cara ini dipandang tidak sesuai lagi dengan pandangan dan perilaku belajar masyarakat belajar yang semakin maju dan berkembang. Teknologi yang semakin maju dan berkembang tidak dapat dipungkiri akan berpengaruh dalam bidang pendidikan. Cara tradisional dapat digantikan dengan teknologi pendidikaan yang telah berkembang dengan memanfaatkan fasilitas yang berhubungan dengan berkembangan teknologi sebagai sumber belajar. Perkembangan teknologi pendidikan membawa dampak yang signifikan dalam bidang pendidikan. Hal ini tidak dapat ditunda-tunda dalam memajukan aktivitas yang membutuhkan teknologi pendidikan didalamnya.

Pemanfaatan teknologi dalam bidang pendidikan dapat berupa pemanfaatan sarana dan rasarana seperti komputer, lcd, layar proyektor, dll, yang dapat mendukung proses pembelajaran menjadi lebih bermakna. Hal ini dapat dibuktikan bahwa banyak sekolah-sekolah telah memiliki fasilitas yang berupa computer, LCD, layar proyektor dan laboratorium komputer. Beberapa sarana dan prasarana tersebut dapat digunakan sebagai alat pendukung multimedia interaktif yang disajikan dalam proses pembelajaran yang dapat menampilkan materi secara visual. Hal ini sejalan dengan apa yang dikemukakan oleh Mayer (2009) disadari atau tidak, kecanggihan teknologi saat ini memungkinkan ledakan akses untuk mendapatkan cara-cara visual dalam menyajikan materi pembelajaran. Pembelajaran tematik pada kurikulum terbaru yang diterapkan di Indonesia mengharuskan siswa belajar dengan kemajuan teknologi yang salah satunya adalah komputer.

Multimedia interaktif memiliki karakteristik yang dapat melibatkan siswa secara langsung dalam pengoperasiannya pada proses pembelajaran sehingga siswa lebih aktif dalam belajar. Untuk menjadikan hal tersebut menjadi nyata membutuhkan pengembangan multimedia interaktif yang berisi materi dan 
kegiatan siswa dikemas dalam proses pembelajarannya. Daryanto (2010) mengatakan, apabila multimedia dipilih, dikembangkan dan digunakan secara tepat dan baik, akan memberi manfaat yang sangat besar bagi para siswa diantaranya adalah proses pembelajaran menjadi lebih menarik, lebih interaktif, jumlah mengajar dapat dikurangi, kualitas belajar siswa dapat ditingkatkan dan proses belajar mengajar dapat dilakukan dimana dan kapan saja, serta sikap belajar siswa dapat ditingkatkan. Selain itu Ariana (2010) juga mengatakan bahwa pembelajaran menggunakan multimedia akan lebih menarik, interaktif, jumah waktu mengajar dengan ceramah dapat dikurangi. Sikap, perhatian belajar siswa ditingkatkan dan dipusatkan, serta kualitas belajar dapat termotivasi.

Multimedia interaktif dapat dijadikan media alternatif untuk menanggulangi permasalahan kualitas pembelajaran di sekolah. Multimedia interaktif dapat mengembangkan kemampuan indera dan menarik perhatian serta minat siswa. Hasil penelitian Computer Technology Research (CTR), menghasilkan bahwa orang hanya mampu mengingat $20 \%$ dari yang dilihat dan $30 \%$ dari yang didengar. Tetapi orang dapat mengingat 50\% dari yang dilihat dan didengar dan $80 \%$ dari yang dilihat, didengar dan dilakukan sekaligus (Munir, 2012). Hasil wawancara dan observasi pada tanggal 17 s/d 19 Agustus 2014 dengan guru kelas IV SD Negeri Merjosari 2 Malang memperoleh beberapa informasi terkait proses pembelajaran yang disukai oleh siswa yaitu belajar dengan multimedia interaktif yang pelasanaanya berada di laboratorium komputer, bukan di dalam kelas. Karena fasilitas seperti layar proyektor, LCD, dan komputer yang tersedia di dalam kelas belum digunakan secara maksimal, Siswa menyukai mata pelajaran yang menempatkan mereka di laboratorium komputer yang menjadikan siswa betah di dalam laboratorium sampai pada saat pergantian jam, siswa belum beranjak untuk meninggalkan laboratorium komputer karena siswa menyukai belajar dengan multimedia interaktif.

Penelitian ini bertujuan untuk mengetahui tingkat kepraktisan penggunaan multimedia interaktif dalam pembelajaran tematik di kelas IV SD. Tingkat kepraktisan dalam penelitian ini dilihat melalui keterterapan multimedia interaktif 
pada proses pembelajaran yang diperoleh dari hasil angket guru, oserver, dan siswa.

\section{METODE PENELITIAN}

Penelitian ini merupakan penelitian kualitatif yang menggunakan metode penelitian deskriptif kualitatif. Penelitian kualitatif menurut Moleong (2014) mengemukakan bahwa penelitian untuk melihat fenomena yang terjadi terkait halhal apa saja yang dialami oleh subjek penelitian seperti motivasi, perilaku, tindakan dll. Penelitian ini dilaksanakan di SDN Merjosari 2 Malang di kelas IV.

Teknik pengumpulan data pada penelitian ini adalah observasi, wawancara, dan pemberian angket. Teknik wawancara dilakukan kepada guru untuk memperoleh tanggapan keterlaksanaan multimedia interaktif pada pembelajaran, teknik observasi menggunakan instrumen lembar observasi untuk melihat keterlaksanaan penggunaan multimedia interaktif yang diberikan oleh observer dalam bentuk angket. Pemberian angket kepada guru dan siswa untuk mendapatkan data terkait keterlaksanaan Multimedia Interaktif diantaranya : a. Kemudahan guru dan siswa melaksanakan pembelajaran dengan multimedia interaktif; b. Kelancaran proses pembelajaran; c. Waktu pelaksanaan; d. Petunjuk multimedia interaktif mudah dipahami.

Data kepraktisan dalam penelitian ini diperoleh dari 2 subjek penelitian yaitu guru dan siswa. Data yang diperoleh dari angket guru dan siswa akan dihitung rata-ratanya kemudian dikonversi sesuai dengan kriteria tingkat kepraktisan. Analisis tingkat kepraktisan produk dalam angket dapat dihitung dengan rumus sebagai berikut :

$$
V p=\frac{T S E p}{S-\max } \times 100 \%
$$

(Akbar dan Sriwiyana, 2011)

Keterangan :

$\mathrm{Vp} \quad=$ Validitas Kepraktisan

TSEp $=$ Total Skor Empirik Kepraktisan

S-max $=$ Skor maksimal yang diharapkan 
Setelah mengetahui nilai kepraktisan, untuk mendeskripsikan hasil kepraktisan dapat dilihat dari kriteria sebagai berikut :

Tabel 1 Kriteria Kepraktisan Multimedia Interaktif

\begin{tabular}{ccl}
\hline Kriteria & Kategori & \multicolumn{1}{c}{ Keterangan } \\
\hline $75,01 \%-100 \%$ & Sangat Praktis & Dapat digunakan tanpa revisi \\
\hline $50,01 \%-75,00 \%$ & Praktis & $\begin{array}{l}\text { Dapat digunakan dengan revisi } \\
\text { kecil }\end{array}$ \\
\hline $25,01 \%-50,00 \%$ & Kurang Praktis & $\begin{array}{l}\text { Disarankan untuk tidak } \\
\text { dipergunakan }\end{array}$ \\
\hline $00,00 \%-25,00 \%$ & Tidak Praktis & Tidak dapat digunakan \\
\hline
\end{tabular}

(Sumber: Diadaptasi dari Akbar, 2011: 208)

\section{HASIL DAN PEMBAHASAN}

Data kepraktisan multimedia interaktif diperoleh dari hasil angket yang disebarkan kepada guru dan siswa setelah menggunakan multimedia interaktif, selain itu data yang mendukung kepraktisan produk multimedia interaktif dari hasil angket yang diberikan kepada observer yang mengamati jalannya penggunaan multimedia interaktif. Tanggapan guru dalam mendukung kepraktisan diperlukan dalam proses pengembangan multimedia interaktif ini. Hasil tanggapan guru terhadap kepraktisan multimedia interaktif disajikan dalam tabel 2 berikut :

Tabel 2 Hasil Agket Kepraktisan oleh Guru

\begin{tabular}{|c|c|c|}
\hline No & Aspek yang Dinilai & \multirow{2}{*}{ Skor } \\
\hline & Kepraktisan & \\
\hline 1. & $\begin{array}{l}\text { Saya tidak merasa kesulitan melaksanakan pembelajaran } \\
\text { menggunakan multimedia interaktif }\end{array}$ & 3 \\
\hline 2. & Saya merasa lancar mengoperasikan multimedia & 3 \\
\hline 3. & $\begin{array}{l}\text { Kemampuan multimedia interaktif untuk dapat digunakan secara } \\
\text { berulang-ulang }\end{array}$ & 4 \\
\hline 4. & $\begin{array}{l}\text { Kesesuaian waktu yang tersedia dalam pembelajaran dengan } \\
\text { kemudahan pengoperasian multimedia interaktif. }\end{array}$ & 4 \\
\hline 5. & $\begin{array}{l}\text { Kemampuan multimedia interaktif membantu siswa memahami } \\
\text { informasi. }\end{array}$ & 3 \\
\hline 6. & $\begin{array}{l}\text { Kemampuan multimedia interaktif dalam memicu kreativitas } \\
\text { siswa }\end{array}$ & 4 \\
\hline 7. & $\begin{array}{l}\text { Kemampuan multimedia interaktif untuk mengaktifkan siswa } \\
\text { dalam membangun pengetahuan sendiri. }\end{array}$ & 4 \\
\hline \multirow[t]{3}{*}{8.} & $\begin{array}{l}\text { Kesesuaian multimedia interaktif dengan dunia siswa yang } \\
\text { sedang diajar. }\end{array}$ & 4 \\
\hline & Total Skor & 29 \\
\hline & Persentase Skor & $90,6 \%$ \\
\hline
\end{tabular}


Tabel di atas menunjukkan bahwa berdasarkan penilaian yang dilakukan oleh guru sebagai pengguna multimedia interaktif ini, persentase kepraktisan multimedia interaktif mencapai 90,6\% dengan kriteria "Sangat Praktis". Hasil tersebut merupakan gabungan dari beberapa aspek diantaranya guru merasa mudah dan lancar dalam mengoperasikan multimedia interaktif, multimedia interaktif penerapannya sangat sesuai dengan waktu pembelajaran dan dapat diulang-ulang sesuai dengan keinginan penggunanya, multimedia interaktif mampu membantu siswa dalam memahami materi, multimedia interaktif juga sangat mampu memnumbuhkan kreatifitas siswa, menumbuhkan pengtahuannya sendiri, dan multimedia interaktif sangat sesuai dengan dunia siswa. Kepraktisan sebuah media sejalan dengan yang dikatakan oleh Nieveen (1999) kepraktisan dapat dilihat dari pengguna produk seperti guru, siswa dan ahli lainnya dalam menggunakan produk tidak mengalami kesulitan, selain itu produk yang dikembangkan memiliki keterlaksanaan yang sesuai. Multimedia interaktif yang dikembangkan dikatakan praktis jika dapat diimplementasikan di lapangan, yang menunjukkan respon guru, siswa dan pengguna lainnya merasa mudah menggunakan multimedia interaktif untuk memahami materi.

Hasil wawancara dengan guru kelas IV SDN Merjosari 2 Malang menjelaskan bahwa terjadi perubahan proses pembelajaran antara menggunakan bahan ajar yang biasa digunakan dengan menggunakan multimedia interaktif, siswa terlihat sangat senang dan cepat memahami materi yang ada di multimedia interaktif. Siswa lebih mudah dikondisikan dalam proses pembelajaran, mereka lebih cepat menyelesaikan tugas, motivasi siswa sangat tinggi terlihat dari antusias siswa terhadap proses pembelajaran menggunakan multimedia interaktif. Multimedia interaktif ini memberikan suasana baru, meningkatkan motivasi belajar siswa, memberikan wawasan yang lebih luas dan mempermudah pemahaman siswa terhadap materi Keanekaragaman Hewan dan Tumbuhan, dapat dijadikan pendamping buku yang diberikan dari pemerintah. Tampilan multimedia interaktif ini terdapat visualisasi tentang materi pembelajaran yang dapat digunakan oleh guru untuk menjelaskan ataupun siswa dalam belajar mandiri. Hal ini diperkuat oleh Lee and Owens (2004) mengatakan “ pada prinsip aplikasi 
multimedia siswa akan belajar ketika menggunakan contoh nyata dan menggunakan ilustrasi yang digunakan untuk mendemonstrasikan konsep dan keterampilan pada saat siswa belajar."

Hasil tanggapan observer dalam kepraktisan diperlukan dalam mengetahui secara langsung penggunaan multimedia interaktif dalam proses pembelajaran disajikan dalam tabel berikut:

Tabel 3 Hasil Angket Observer Kepraktisan

\begin{tabular}{|c|c|c|}
\hline No & Aspek yang Dinilai & Skor \\
\hline \multicolumn{3}{|c|}{ Kepraktisan } \\
\hline 1. & $\begin{array}{l}\text { Guru tidak merasa kesulitan melaksanakan pembelajaran menggunakan } \\
\text { multimedia interaktif. }\end{array}$ & 3 \\
\hline 2. & Guru lancar mengoperasikan multimedia interaktif. & 3 \\
\hline 3. & $\begin{array}{l}\text { Multimedia interaktif dapat digunakan secara berulang-ulang oleh guru dan } \\
\text { siswa. }\end{array}$ & 4 \\
\hline 4. & $\begin{array}{l}\text { Kesesuaian waktu yang tersedia dalam pembelajaran dengan kemudahan } \\
\text { pengoperasian multimedia interaktif. }\end{array}$ & 4 \\
\hline 5. & $\begin{array}{l}\text { Multimedia interaktif membantu siswa memahami informasi dalam proses } \\
\text { pembelajaran. }\end{array}$ & 3 \\
\hline 6. & Multimedia interaktif dalam memicu kreativitas siswa. & 4 \\
\hline 7. & $\begin{array}{l}\text { Kemampuan multimedia interaktif untuk mengaktifkan siswa dalam } \\
\text { membangun pengetahuan sendiri. }\end{array}$ & 4 \\
\hline 8. & Kesesuaian multimedia interaktif dengan dunia siswa yang sedang diajar. & 3 \\
\hline 9. & Siswa lancar mengoperasikan multimedia interaktif. & 4 \\
\hline 10. & $\begin{array}{l}\text { Proses pembelajaran menggunakan multimedia interaktif sesuai dengan } \\
\text { kegiatan siswa. }\end{array}$ & 3 \\
\hline 11. & Multimedia interaktif sesuai dengan isi materi pembelajaran tematik. & 4 \\
\hline 12. & Suasana proses pembelajaran berjalan kondusif dan menyenangkan. & 4 \\
\hline 13. & Siswa lebih cepat memahami materi dengan multimedia interaktif. & 4 \\
\hline 14. & Multimedia interaktif memudahkan guru dalam mengajar. & 4 \\
\hline 15. & $\begin{array}{l}\text { Siswa lebih cepat menyelesaikan tugas individu dan kelompok dengan } \\
\text { sumber belajar multimedia interaktif. }\end{array}$ & 3 \\
\hline \multicolumn{2}{|r|}{ Total Skor } & 54 \\
\hline \multicolumn{2}{|r|}{ Persentase Skor } & $90 \%$ \\
\hline
\end{tabular}

Tabel di atas menunjukkan bahwa penilaian yang dilakukan oleh observer pada kepraktisan produk multimedia interaktif dengan persentase nilai $90 \%$ dengan kriteria "Sangat Praktis". Hasil tanggapan observer tersebut didapatkan pada saat observer mengamati pelaksanaan penggunaan multimedia interaktif dari beberapa aspek diantaranya dari hasil pengamatan kepada guru dan siswa. Guru dan siswa merasa mudah dan lancar dalam mengoperasikan multimedia interaktif, multimedia interaktif penerapannya sangat sesuai dengan waktu pembelajaran dan dapat diulang-ulang sesuai dengan keinginan penggunanya, multimedia interaktif 
mampu membantu siswa dalam memahami materi, multimedia interaktif juga sangat mampu memnumbuhkan kreatifitas siswa, menumbuhkan pengtahuannya sendiri, dan multimedia interaktif sangat sesuai dengan dunia siswa, suasana pembelajaran menjadi sangat kondusif, multimedia interaktif sangat membantu siswa cepat memahami materi, memudahkan guru dalam mengajar, dan membantu siswa lebih cepat dalam mengerjakan tugas.

Tanggapan siswa dalam kepraktisan diperlukan dalam penggunaa multimedia interaktif. Pengumpulan data kepraktisan dengan memberikan angket kepada siswa yang diisi setelah belajar dengan menggunakan multimedia interaktif. Tanggapan siswa dalam menggunakan multimedia interaktif dapat dilihat pada tabel berikut:

Tabel 4 Hasil Angket Kepraktisan oleh Siswa

\begin{tabular}{|c|c|c|c|c|}
\hline \multirow{2}{*}{ No } & \multirow{2}{*}{ Aspek yang Dinilai } & \multicolumn{3}{|c|}{ Skor Perolehan Siswa } \\
\hline & & \multirow[t]{2}{*}{1} & \multirow[t]{2}{*}{2} & \multirow[t]{2}{*}{3} \\
\hline & Kepraktisan & & & \\
\hline 1. & $\begin{array}{l}\text { Saya mudah memahami materi dengan melihat gambar- } \\
\text { gambar tentang hewan dan tumbuhan yang ada di } \\
\text { Indonesia. }\end{array}$ & & 0 & 15 \\
\hline 2. & $\begin{array}{l}\text { Saya lebih mudah mengenal hewan dan tumbuhan khas } \\
\text { nusantara melalui kegiatan yang saya lakukan }\end{array}$ & & 2 & 13 \\
\hline 3. & $\begin{array}{l}\text { Saya lebih mudah mengerjakan soal latihan yang ada di } \\
\text { buku dengan bantuan multimedia interaktif. }\end{array}$ & & 2 & 13 \\
\hline 4. & $\begin{array}{l}\text { Saya mudah memahami bahasa dan perintah yang ada di } \\
\text { multimedia interaktif }\end{array}$ & & 3 & 12 \\
\hline 5. & $\begin{array}{l}\text { Saya tidak mengalami kesulitan dalam menggunakan } \\
\text { multimedia interaktif. }\end{array}$ & & 6 & 9 \\
\hline & Jumlah Skor & $\mathbf{0}$ & 32 & 186 \\
\hline & Jumlah Skor Perolehan & & 212 & \\
\hline & Skor Maksimal & & 225 & \\
\hline & Persentase & & $94,2 \%$ & \\
\hline
\end{tabular}

Tabel di atas, menunjukkan bahwa penilaian siswa terhadap kepraktisan multimedia interaktif mencapai persentase 94,2\% dengan kriteria "Sangat Praktis", sehingga dapat digunakan dalam proses pembelajaran. Hasil persentase tersebut merupakan gabungan dari beberapa aspek yaitu multimedia sangat membantu sebagian besar siswa dalam memvisualkan materi terkait keanekaragaman hewan dan tumbuhan, siswa lebih mengenal lebih dalam terkait materi yang dipelajari, siswa lebih mudah mengerjakan soal yang ada di buku dengan bantuan multimedia interaktif, dan siswa tidak mengalami kesulitan dalam 
mengoperasikan multimedia interaktif. Hasil analisis keseluruhan terkait kepraktisan penggunaan multimedia interaktif menunjukkan bahwa multimedia interaktif sangat praktis untuk digunakan dalam proses pembelajaran, hasil ini sangat sesuai dengan hasil penelitian tentang multimedia interaktif yang dilakukan oleh Rachmadyanti (2013) hasil penelitiannya menunjukkan bahwa penggunan multimedia interaktif sangat sesuai untuk diterapkan dalam pembelajaran. hal ini menunjukkan bahwa multimedia interaktif dapat dijadikan alternatif media pembelajaran.

Hasil tingkat kepraktisan multimedia interaktif yang diperoleh dari hasil angket guru, observer, dan siswa disajikan dalam bentuk diagram 1 .

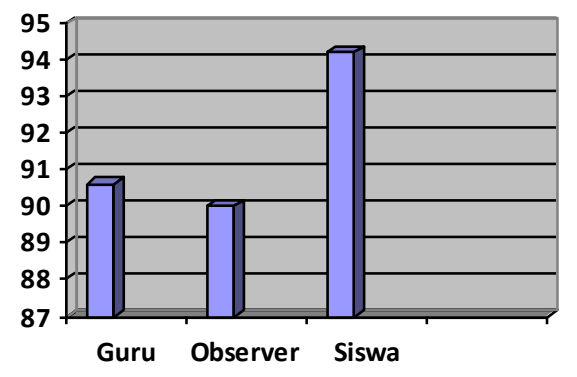

\section{Diagram 1 Kepraktisan}

Diagram di atas menunjukkan nilai persentase tertinggi pada hasil yang diperoleh dari siswa, hal ini menunjukkan tingkat kepraktisan multimedia interaktif sangat praktis, karena pengguna yang utama adalah siswa dalam menggunakan multimedia interaktif dalam pembelajaran. Data ini menunjukkan bahwa, multimedia interaktif dapat dijadikan salah satu media alternatif yang dapat membantu siswa dan guru dalam pelaksanaan pembelajaran dan memahami materi yang dipelajari. Salah satu faktor yang terjadi dari hasil observasi yang menjadi alasan multimedia interaktif sebagai alternatif pemecahan masalah sebagaimana yang dikemukakan oleh Sadiman (2010), adalah "beragam retensi belajar siswa dalam menyerap dan memahami penyajian konten pembelajaran”. Faktanya tidak semua siswa cocok pada satu kondisi pembelajaran. Oleh karena itu, guru memiliki peran penting untuk menciptakan proses pembelajaran yang berorientasi tinggi terhadap pencapaian tujuan dan hasil belajar siswa secara 
menyeluruh, yaitu melalui pemanfaatan multimedia interaktif dalam proses pembelajaran.

\section{KESIMPULAN DAN SARAN}

Hasil analisis dari angket oleh guru diperoleh persentase 90,6\%, dimana persentase tersebut termasuk dalam kriteria "Sangat Praktis". Hasil wawancara dengan guru dapat dijelaskan bahwa multimedia interaktif ini memberikan suasana baru, meningkatkan motivasi belajar siswa, memberikan wawasan yang lebih luas dan mempermudah pemahaman siswa terhadap materi. Berdasarkan hasil analisis angket dari observer menunjukkan 90\% dengan kriteria "Sangat Praktis". Sedangkan hasil angket siswa menunjukkan 94,2\% dengan kriteria "Sangat Praktis". Dapat disimpulkan bahwa kepraktisan penggunaan multimedia interaktif dalam pembelajaran tematik kelas IV termasuk dalam kriteria sangat praktis untuk digunakan dalam proses pembelajaran. Selain itu dapat dipastikan guru dan siswa tidak mengalami kesulitan dalam menggunakan multimedia interaktif sebagai salah satu alternatif media pembelajaran untuk menjadikan pembelajaran lebih berkualitas. Kesimpulan tersebut sejalan dengan pendapat Praherdiono dan Adi (2008) yang mengatakan multimedia menjadi alat yang ampuh untuk pengajaran dan pendidikan serta untuk meraih keunggulan bersaing baik sekolah, perguruan tinggi maupun penyelenggara pendidikan lainnya.

Saran untuk penelitian selanjutnya ialah penggunaan multimedia interaktif tidak hanya pada satu sekolah, tetapi lebih dari satu sekolah sehingga hasil kepraktisan akan terlihat lebih menyeluruh digunakan di SD kota dan SD yang terdapat di desa. Penggunaan multimedia interaktif tidak hanya digunakan pada pembelajaran tematik, tetapi dapat digunakan pada pembelajaran lainnya.

\section{DAFTAR PUSTAKA}

Akbar, Sa'dun.2011.Pengembangan Kurikulum dan Pembelajaran Ilmu Pengetahuan Sosial.Yogyakarta: Cipta Media.

Akbar, Sa'dun.2013.Instrumen Perangkat Pembelajaran.Bandung: Remaja Rosdakarya. 
Ariani, N. \& H. 2010. Pembelajaran Multimedia di Sekolah Pedoman Pembelajaran Inspiratif, Konstruktif, dan Prospektif. Jakarta: PT Prestasi Pustakarya.

Daryanto. 2013. Media Pembelajaran: PeranannyaSangat Penting Dalam Mencapai Tujuan Pembelajaran. Yogyakarta: Gava Media

Praherdhiono, Henry \& Eka Pramono Adi. 2008. Panduan Praktikum Multimedia. Malang: Fakultas Ilmu Pendidikan Universitas Negeri Malang.

Mayern, Richard E.2009. Multi-Media Learning. Yogyakarta:Pustaka Pelajar.

Munir. 2012. Multimedia Konsep \& Aplikasi dalam Pendidikan. Bandung: Alfabeta.

Nieveen, N.M. (1999). Prototyping to reach productquality. In J. van den Akker, R. Branch, K. Gustafson, N. Nieveen \& T. Plomp (Eds.) Design approaches and tools in education and training(pp. 125-136).Dordrecht, The Netherlands: Kluwer AcademicPublishers.

Lee, W. \& Owens, D, L. 2004. Multimedia Based Instructional Design, Second Edition. United States of Amrica: John Wiley \& Sonc. Inc.

Rachmadyanti, Putri.2013. Pengembangan Multimedia Interaktif Dalam Pembelajaran IPS (Studi Empiris pada Siswa kelas IV SDN Kendalrejo 02 Kecamatan Talun Kabupaten Blitar. Tesis Tidak diterbitkan. Malang:PPs UM.

Sadiman, Arif. S. dkk.2009. Media Pendidikan, Pengembangan dan Pemanfaatannya. Jakarta: Pustekkom Dikbud dan PT Raja Grafindo Persada. 